\title{
Psychological Problems among Orphan Children
}

\section{Asmaa Mohamed El-Said Abd-Alla ${ }^{1}$, Sorayia Ramadan Abd-Elfatah ${ }^{2}$, Mawaheb Mahmoud} Zaki $^{3}$ and Hend Ahmed Mostafa Hassinine ${ }^{4}$

(1) Nursing Supervisor at Benha Fever, Liver and Digestive System Hospital, Egypt, (2) Professor of Psychiatric and Mental Health Nursing, Faculty of Nursing, Ain Shams University, Egypt, (3) Assistant Professor of Psychiatric and Mental Health Nursing, Faculty of Nursing, Benha University, Egypt and (4) Lecturer of Psychiatric and Mental Health Nursing, Faculty of Nursing, Benha University, Egypt

\begin{abstract}
Background: Orphan hood is a time which involves many psychological problems. Lack of self-esteem and inability to take decision puts orphans at risk of anxiety and depression. Aim of study: Was to assess the psychological problems among orphan children. Research design: A descriptive design was utilized to achieve the aim of the study. Setting: This study was conducted at social home care for males and females in Benha City, Qalubyia Governorate. Sample: A purposive sample of (80) orphan children (40 males \& 40 females) who was selected from the above mention setting. Tools for data collection: Three tools were used. I: A structured interviewing questionnaires sheet. II: Child anxiety and depression scale and III: Rosenberg selfesteem scale. Results: Half of the studied orphan children had moderate level of total anxiety and depression. In addition more than half of studied orphan children had low level of self-esteem. While less than one quarter of them had moderate level of self-esteem. Conclusion: Emotional distress and lack of self-esteem are the major psychological problems among orphan children which necessitate great concern. Recommendations: Psychosocial counseling program can be designed and administered to orphan children to improve their behavioral and psychological problems.
\end{abstract}

Key words: Orphan children, Psychological problems

\section{Introduction}

Losing a parent or both is a double tragedy to children. Not only do they have to deal with the experience of loss and grief associated with parental loss, but also the additional stressors that arise after the parent's death. Compared to non-orphans, the term orphan defined as a child under age of 18 years who lost one or both parents resulted from death from any cause. Orphans are more exposed to malnutrition, poor physical and mental health; educational disadvantages stress and anxiety (Abdel Hakeem et al., 2018).

Psychological problems are more among orphans and other vulnerable children because they are exposed to abuse, exploitation, neglect, lack of love and care of parents. They are also more likely to be emotionally needy, insecure, and poor. In addition to these factors, most of them are brought up in institutional homes where individual care is inadequate. All these factors can socially and emotionally impair these children (Elattar et al. 2019).

Depression is common psychological problems that occurs among orphan children and defined by certain emotional, behavioral, and thought patterns. Anxiety is another psychological problem among orphan children and defined as a fearful situation in which a person feels hesitant to talk or interact with the feared object, and exhibit high anxiety, phobia, emotional and behavioral problems (Shafiq et al., 2020).

Self-esteem is also psychologically affected among orphan children and it is used 
to describe a person's overall subjective sense of personal worth or value. Some researchers found that orphan children show lower selfesteem than their non- orphan peers who have a much closer relationship with their parents (Johnson, 2020).

\section{Significant of the study}

Orphans children living in institutional homes are more prone to behavioral and emotional problems than others as they are deprived of a family's love and care. There is a dearth of studies focusing on the psychological health of these children in Egypt. Hence, we have conducted a crosssectional descriptive study to assess the psychological problems in these institutionalized children (Kaur, 2018).

In Egypt, there are 250 orphanages hosting 7749 children between 6 and 18 years old, including 102 orphanages hosting 2068 children between 1 and 6 years old. Governmental Orphanage assumed to accept children from 6 to 18 years. These orphanages or shelters provide social and healthcare as well as educational, religious, and recreational activities for children deprived of family care (El-Slamoni et al., 2019).

\section{Aim of the study}

This study aimed to assess the psychological problems among orphan children.

\section{Research Questions:}

1) What are the symptoms of anxiety among orphan children?

2) What are the symptoms of depression among orphan children?

3) What is the level of self-esteem among orphan children?

\section{Subject and Methods}

\section{Research design}

A descriptive design was used to conduct this study.

\section{Research setting}

The study was conducted at Social Home Care for males and females in Benha City, Qalubyia Governorate

\section{Sample:}

\section{Sample Size:}

The sample size in this study included 80 child who were subjected from social home care for males (40) and social home care for females (40) in Benha City. Sample size has been calculated using the following equation: $\mathrm{n}=\left(\mathrm{z}^{2} \mathrm{xpxq}\right) \mathrm{D}^{2}$ at power $80 \%$ and CI $95 \%$

\section{Sampling Type:}

A purposive sample of children who were living in the previously mentioned setting according to the following inclusion and exclusion criteria:

\section{Inclusion criteria:}

1) Aged from 6 to 18 years.

2) Both sexes.

3) Willing to participate in the study.

\section{Exclusion criteria:}

1) Children with psychotic disorders.

2) Children with visual and hearing impairment.

\section{Tools of data collection}

In order to achieve the aim of the study, the following tools were used:-

\section{Tool (I): A Structured Interviewing Questionnaire Sheet:}

It was designed by the researcher after reviewing the related literature. It was written in an Arabic language for gathering data and consisting of three parts:

Part (1): Socio-demographic data for orphaned children such as age, sex, education 
level, have Siblings, ranking of child in family.

Part (2): Knowledge about Child's Life in Hostel Institutions such as child age at time of admission, duration of stay in hostel institutions, method and causes of admission, relationship with those friends and who take care for him inside the hostel institution.

Part (3): Knowledge about Child's Life in the School such as academic performance, have friends at school, how to deal with their colleagues, teachers and administrators at school.

Tool (II):- Child Anxiety and Depression Scale: It was adopted by (Chorpita et al., 2000). It was used to assess symptoms of anxiety and depression among orphan children.

\section{Scoring system:}

The scale was consisted of 47 items divided as Separation Anxiety subscale (7 items), Social Phobia subscale (9 items), Generalized Anxiety subscale (6 items), panic disorder subscale (9 items), ObsessiveCompulsive subscale (6 items) and Major Depression subscale (10 items). The total score of the scale was 141 grades. Each statement was scored 0 to 3 corresponding to never, some-times, often and always.

- Normal level if score $<25 \%$ ( $<36$ grades).

- Mild level if score $25-<50 \% \quad(36-<71$ grades).

- Moderate level if score from 50-<75\% (71$<106$ grades).

- Severe level if score $\geq 75 \%$ ( $\geq 106$ grades).

Tool (III):- Rosenberg Self-Esteem Scale: The scale was developed by (Rosenberg, 1965). It was used to assess self-esteem among orphan children.

\section{Scoring system:}

The scale was consisted of 10 items 5 positive and 5 negative graded statements to assess self-esteem. Statement for items from
(1-5): is answered as (3) strongly agree, (2) agree, (1) disagree or (0) strongly disagree, but for items from (6-10) reversed in valence; the scale ranges from 0-30.

The total score is 30 and the scoring system is categorized as following:

(0-15) grades low self-esteem

(16-21) grades moderate self-esteem

(22-30) grades high self-esteem

\section{Validity of the tools:}

It was ascertained by (5) experts in psychiatric and mental health nursing. Their opinions elicited regarding the format, layout, consistency, accuracy and relevancy of the tools.

\section{Reliability of the tools}

Reliability analysis by measuring of internal consistency of the tool through Cronbach's Alpha (test - retest).

\begin{tabular}{|c|c|c|}
\hline Tool & $\begin{array}{c}\text { Cronbach's } \\
\text { Alpha }\end{array}$ & $\begin{array}{c}\text { Internal } \\
\text { consistency }\end{array}$ \\
\hline $\begin{array}{c}\text { Child } \\
\text { Anxiety } \\
\text { and } \\
\text { Depression } \\
\text { Scale }\end{array}$ & .863 & Good \\
\hline $\begin{array}{c}\text { Rosenberg } \\
\text { Self- } \\
\text { Esteem } \\
\text { Scale }\end{array}$ & .921 & Strong \\
\hline
\end{tabular}

\section{Ethical considerations:}

All subjects were informed that participation in the study is voluntary; no name will be included in the questionnaire sheet. Anonymity confidentiality of each participant was respected and protected, confidentiality was assured and subjects was informed that the content of the tool was used for research purpose only and they have the right of refuse to participate in the study or 
withdrawal at any time without any consequences.

\section{Pilot study}

Carried out on 8 children those represent $10 \%$ of children under the study. In order to test the applicability of the constructed tools and the clarity of the included questions. The pilot has also served to estimate the time needed for each subject to fill in the questions. This sample was excluded from the actual study sample.

\section{Field work:}

After securing the official permission from the dean of Banha faculty of nursing to the directors of social home care, the researcher met the directors of social home care before applying of the study to determine the suitable time to meet the study participants and explain the aim and objectives of the study.

The actual fieldwork for the process of the data collection has consumed 2.5 monthes started at beginning of January 2021 and was completed by the middle of March 2021.

The researcher introduced herself to subjects then explain the aim of the study to each one of them. Oral consent was obtained from every participant who fulfills the inclusion criteria. The researcher was collecting the data from the subjects at 2 days (Sunday and Tuesday) / weeks at morning shift (10a.m-1p.m) to collect data. The researcher was meeting with a number of students ranging from 4-5 students in each meeting. The questionnaire for Child Anxiety and Depression Scale was filled by the researcher, which take 25-30 minutes. In addition, the researcher filled the Rosenberg Self-Esteem Scale in 15-20 minutes.

\section{Statistical analysis}

Data collected from the studied sample was revised, coded and entered using Personal Computer (PC). Computerized data entry and Statistical analysis were fulfilled using the Statistical Package for Social Sciences (SPSS) version 25 (SPSS Inc., Chicago, IL, USA). Data were presented using descriptive statistics in the form of frequencies and percentage for categorical data, the arithmetic mean (X) and standard deviation (SD) for quantitative data. Chi-square test $\left(\mathrm{X}^{2}\right)$ was used for comparisons between qualitative variables. Spearman correlation measures the strength and direction of association between two ranked variables

\section{Results}

Table (1): Shows that, more than half $(52.5 \%)$ of the studied children their age ranged between $6-<9$ years, the Mean \pm SD of age is $8.8 \pm 3.97$ years. In addition, more than three quarters $(77.5 \%)$ of them at primary school. Moreover, more than half $(52.5 \%)$ of them do not have sibling. Also, nearly two-thirds $(65 \%)$ of them are the first child.

Table (2): Reveals that, nearly twothirds $(65 \%)$ of the studied children their age at time of admission ranged from 6 years to less than 12 years and half $(50 \%)$ of the studied children stay in hostel institutions from a year to less than 5 years. Moreover, the majority $(90 \%)$ of the studied children join the institution by their families and less than two thirds $(60 \%)$ of the studied children stay in a hostel institution due to the death of parents. Moreover, three quarters (75\%) of the studied children deal aggressive with who take care for them in the orphanage and the vast majority $(95 \%)$ of them have friends at the orphanage, more than half $(57.9 \%)$ of the studied children deal aggressive with their friends. 
Table (3): Reveals that, nearly half $(47.5 \%)$ of the studied children have acceptable level at school and the majority $(87.5 \%)$ of them had friends at school. Moreover, nearly three quarters and more than half of the studied children deal aggressively with their friends and teachers at school (71.4\% and $56.2 \%$, respectively). Also, nearly two thirds and all of the studied children, their friends and teachers know that they are resident of an orphanage $(60 \%$ and $100 \%$, respectively).

Figure (1): Shows that, half $(50 \%)$ of the studied children had moderate level of total anxiety and depression and less than one quarter $(22.5 \%)$ of them had mild level. In addition, the minority $(12.5 \%)$ of them had severe level. While, $15 \%$ of the studied children had normal level of total anxiety and depression.

Figure (2): Shows that, more than half (60\%) of the studied children had low level of self-esteem. While, less than one quarter $(22.5 \%)$ of them had moderate level of selfesteem and the minority $(17.5 \%)$ of them had high level of self-esteem.

Table (4): Indicates that, there is a highly statistically significant negative correlation between total child anxiety and depression scale and total self-esteem scale among the studied children at $(\mathrm{P}=<0.001)$.

Table (1): Percentage distribution of the studied children according to their sociodemographic data $(\mathbf{n}=\mathbf{8 0})$.

\begin{tabular}{|c|c|c|}
\hline \multirow{2}{*}{ Socio-demographic data } & \multicolumn{2}{|c|}{ Studied sample $(\mathrm{n}=\mathbf{8 0})$} \\
\hline & $\mathbf{N}$ & $\%$ \\
\hline \multicolumn{3}{|l|}{ 1) Age (year) } \\
\hline $6<9$ Years & 42 & 52.5 \\
\hline $9-<12$ Years & 21 & 26.3 \\
\hline $12-<15$ Years & 10 & 12.5 \\
\hline $15-\leq 18$ Years & 7 & 8.7 \\
\hline Mean \pm SD & \multicolumn{2}{|c|}{$8.8 \pm 3.97$} \\
\hline \multicolumn{3}{|l|}{ 2) Sex } \\
\hline Male & 40 & 50 \\
\hline Female & 40 & 50 \\
\hline \multicolumn{3}{|l|}{ 3) Education Level } \\
\hline Primary & 62 & 77.5 \\
\hline Preparatory & 12 & 15 \\
\hline Secondary & 6 & 7.5 \\
\hline \multicolumn{3}{|l|}{ 4) Have Siblings } \\
\hline No & 42 & 52.5 \\
\hline 1 & 32 & 40 \\
\hline 2 & 4 & 5 \\
\hline 3 or more & 2 & 2.5 \\
\hline \multicolumn{3}{|l|}{ 5) Ranking } \\
\hline First & 52 & 65 \\
\hline Second & 22 & 27.5 \\
\hline Third & 4 & 5 \\
\hline Fourth and more & 2 & 2.5 \\
\hline Do not know & 0 & 0.0 \\
\hline
\end{tabular}


Zeinab Yehia Abdel-Naby, Rania Abdel-Hamid Zaki and Faten Mohamed Ahmed

Table (2): Percentage distribution of the studied children according to their knowledge about hostel institutions life $(n=80)$.

\begin{tabular}{|c|c|c|}
\hline \multirow[t]{2}{*}{ Items } & \multicolumn{2}{|c|}{$\begin{array}{l}\text { Studied sample } \\
\quad(\mathbf{n}=\mathbf{8 0})\end{array}$} \\
\hline & $\mathbf{N}$ & $\%$ \\
\hline \multicolumn{3}{|l|}{ 1) Child age at time of admission } \\
\hline From 6 years to less than 10 years & 24 & 30 \\
\hline From 10 years to less than 14 years & 52 & 65 \\
\hline From 14 years to 18 years & 4 & 5 \\
\hline \multicolumn{3}{|c|}{$\begin{array}{cc}\text { Mean SD } & 6.8 \pm 3.99 \\
\end{array}$} \\
\hline \multicolumn{3}{|c|}{ 2) Duration of stay in hostel institutions } \\
\hline From a year to less than 5 years & 40 & 50 \\
\hline From 5 to less than 10 years & 22 & 27.5 \\
\hline From 10 years and more & 18 & 22.5 \\
\hline \multicolumn{3}{|c|}{$\begin{array}{cc}\text { Mean SD } & 6.2 \pm 2.74 \\
\end{array}$} \\
\hline \multicolumn{3}{|c|}{ 3) How did you join the institution? } \\
\hline By family & 72 & 90 \\
\hline By police & 8 & 10 \\
\hline \multicolumn{3}{|c|}{ 4) Causes of staying in hostel institution } \\
\hline Death of Parents & 48 & 60 \\
\hline Death of father & 12 & 15 \\
\hline Death of mother & 6 & 7.5 \\
\hline Broken Families & 5 & 6.2 \\
\hline Illegal & 9 & 11.3 \\
\hline Others & 0 & 0.0 \\
\hline \multicolumn{3}{|c|}{$\begin{array}{l}\text { 5) The relationship with those who take care for you in the } \\
\text { orphanage }\end{array}$} \\
\hline Friendly & 15 & 18.8 \\
\hline Aggressive & 60 & 75 \\
\hline Do not care & 5 & 6.2 \\
\hline \multicolumn{3}{|c|}{ 6) Do you have friends at the Orphanage? } \\
\hline Yes & 76 & 95 \\
\hline No & 4 & 5 \\
\hline \multicolumn{3}{|c|}{ 7) The relationship with your friends at the orphanage $(n=76)$. } \\
\hline Friendly & 18 & 23.7 \\
\hline Aggressive & 44 & 57.9 \\
\hline Do not care & 14 & 18.4 \\
\hline
\end{tabular}


Table (3): Percentage distribution of the studied children according to their knowledge about school life $(\mathbf{n}=\mathbf{8 0})$.

\begin{tabular}{|c|c|c|}
\hline \multirow{2}{*}{ Items } & \multicolumn{2}{|c|}{ Studied sample $(\mathrm{n}=\mathbf{8 0})$} \\
\hline & $\mathbf{N}$ & $\%$ \\
\hline \multicolumn{3}{|c|}{ 1) Academic performance } \\
\hline Weak & 10 & 12.5 \\
\hline Acceptable & 38 & 47.5 \\
\hline Good & 14 & 17.5 \\
\hline Very good & 10 & 12.5 \\
\hline Excellent & 8 & 10 \\
\hline \multicolumn{3}{|c|}{ 2) Do you have Friends at school? } \\
\hline Yes & 70 & 87.5 \\
\hline No & 10 & 12.5 \\
\hline \multicolumn{3}{|c|}{ How do you deal with your friends at school? $(n=70)$} \\
\hline Friendly & 10 & 14.3 \\
\hline Aggressive & 50 & 71.4 \\
\hline Do not care & 10 & 14.3 \\
\hline \multicolumn{3}{|c|}{ 3) How do you deal with your teachers? } \\
\hline Friendly & 25 & 31.3 \\
\hline Aggressive & 45 & 56.2 \\
\hline Do not care & 10 & 12.5 \\
\hline \multicolumn{3}{|c|}{ 4) Do your friends know that you are resident of an orphanage? } \\
\hline Yes & 48 & 60 \\
\hline No & 32 & 40 \\
\hline \multicolumn{3}{|c|}{ 5) Do the teachers know that you are living in an orphanage? } \\
\hline Yes & 80 & 100 \\
\hline No & 0 & 0.0 \\
\hline
\end{tabular}

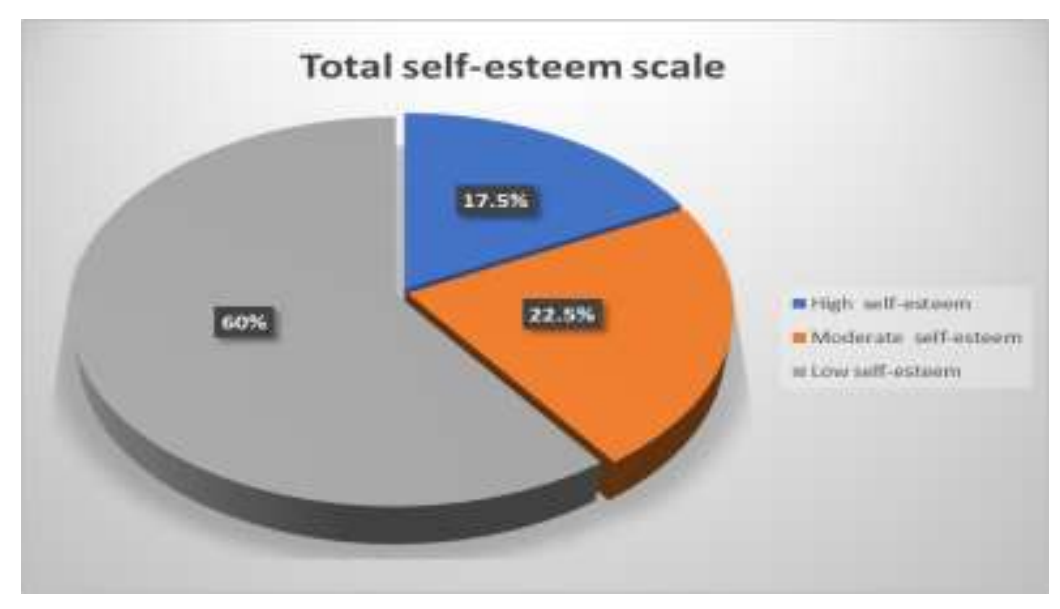

Figure (1): Percentage distribution of the studied children according to their total child anxiety and depression scale. 


\section{Zeinab Yehia Abdel-Naby, Rania Abdel-Hamid Zaki and Faten Mohamed Ahmed}

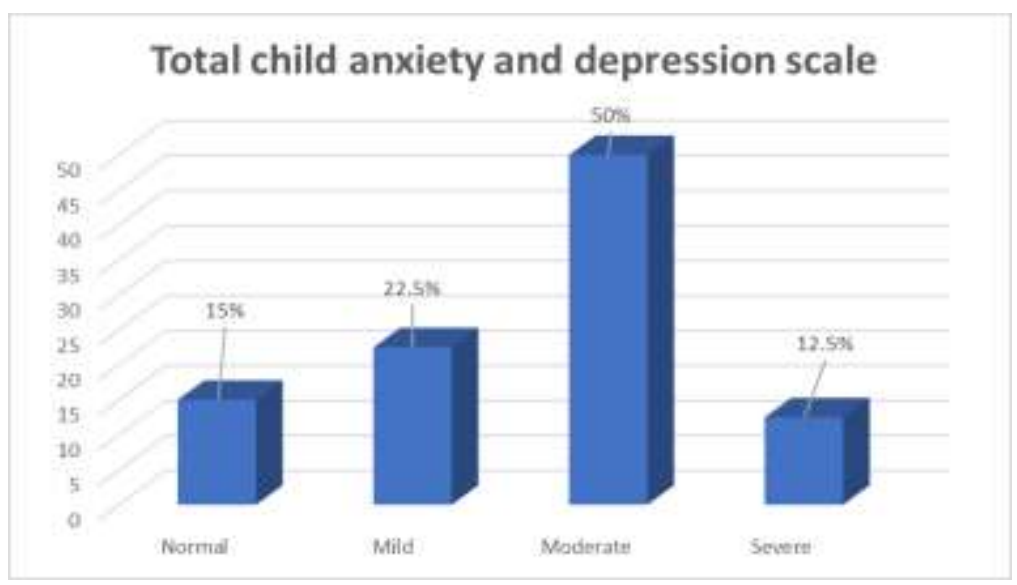

Figure (2): Percentage distribution of the studied children according to their total self-esteem scale

Table (4): Correlation between total child anxiety and depression scale and total self-esteem scale among the studied children

\begin{tabular}{|c|c|c|}
\hline Items & \multicolumn{2}{|c|}{ Total self-esteem scale } \\
\hline \multirow{2}{*}{ Total child anxiety and depression scale } & $\mathrm{R}$ & $\mathrm{p}$-value** \\
\cline { 2 - 3 } & -.405 & $<\mathbf{0 . 0 0 1 * *}$ \\
\hline
\end{tabular}

**highly significant at $\mathbf{p}<\mathbf{0 . 0 0 1}$.

\section{Discussion}

Regarding to the socio-demographic data of the studied orphan children, the findings of the current study revealed that, more than half of the studied orphan children their age ranged between $6-<9$ years, the Mean \pm SD of age is $8.8 \pm 3.97$ years. These results could be due to the age of admission to orphanage starts from 6 years and the orphanage don't receive any child below 6 years. These results were similar with the study of Kovalenko (2018) who revealed that the Mean SD of children's' age was $\mathrm{M}=8.04$, $\mathrm{SD}=3.98$ years.
In addition, the current study results revealed that, more than three quarters of the studied children at primary school. These results might be due to more than half of the studied sample were aged from $6-<12$ years and this the age of primary school stage. These results approved with the study performed by Dhaka \& Mukwiilongo (2020) who stated that more than half of his study participants were in primary school, followed by the participants at the secondary level.

The present study findings reported that, more than half of the studied orphan children do not have sibling and were the first child. These results could be due to orphan 


\section{Asmaa Mohamed, Sorayia Ramadan, Mawaheb Mahmoud, Hend Ahmed}

children were placed in the orphanage at very young age because of their parents' death. These results were similar with the study of El-Slamoni \& Hussien (2019) who revealed that more than three quarters of the studied children do not have sibling and were the first child. On other hand, this result was contradicted with the study of Saboula et al., (2017) who revealed that the higher percent of his studied orphan children having siblings and was ranked the fourth order in their families.

According to knowledge about child's life in hostel institutions, the results of the current study reflect that, nearly two-thirds of the studied children their age at time of admission ranged from 6 years to less than 10 years and half of the studied children stay in hostel institutions from a year to less than 5 years. These results might be due to the orphanage don't accept any child less than 6 years. These current results were supported with the study done by Elattar et al. (2019) who stated that less than three quarters of the orphan children were aged six to less than ten years at the time of admission. Also, the duration of the orphans' stay in the orphanage was between $1-<5$ years.

The present study findings reported that, the majority of the studied children join the institution by their families These results could be due to children are placed in an orphanage because of their parents' death and their families can't afford to or don't want to take care of them so, they placed these children inside orphanages. These results were consistent with the study done by Hakeem et al., (2018) who mentioned that more than two thirds of orphan children admitted the hostel institution by their families. As well as, the common causes of placement in the hostel institutions. As stated by slightly less than half of the orphan children were death of parents.
According to knowledge about child's life in the school, the present study results illustrated that, nearly half of the studied children have acceptable level at school and the majority of the studied children had friends at school. Moreover, nearly two thirds and more than half of the studied children deal aggressively with their friends and teachers at school, respectively. These results could be due to their childhood background and their long stay inside the orphanage which leads to negative feeling such as the feelings of mistrust, insecurity, risk of neglect, stress, and anxiety. Which may in turn leads children to deal aggressively with others and prefer to be social isolated for long period of time.

These results were approved with the study of Elattar et al., (2019) who revealed that more than half of the studied children have average level at school and dealing aggressively with their friends and teachers. In the same field, these results were similar with the study of Helles (2021) who indicated that more than half of the orphan children deal aggressively with their friends and teachers at school.

Moreover, the present study results showed that, nearly two thirds and all of the studied children, their friends and teachers know that they are resident of an orphanage, respectively. These results were in agreement with the study of Devidas \& Mendonca (2017) who revealed that the majority of the studied sample reported that their friends and teachers knowing that they are resident inside an orphanage.

Regarding to total children anxiety and depression scale, the finding of the current study revealed that, half of the studied children had moderate level of total anxiety and depression and less than one quarter of them had mild level. These findings might be due to the feeling of loss, anxiety and 


\section{Zeinab Yehia Abdel-Naby, Rania Abdel-Hamid Zaki and Faten Mohamed Ahmed}

depression that are caused by many factors: The separation from one or both parents and their family, the emotional pain of being rejected and the psychological trauma related to the atmosphere of orphanages. So, the children felt mistrust, insecurity and might be exposed to neglecting and abuse.

These results were approved with the study of Shiferaw et al., (2018) who stated that the prevalence of anxiety and depressive disorders is slightly higher among three quarters of his studied sample. In the same field, these results were in agreement with the study of Shafiq et al., (2020) who revealed that higher levels of social and general anxiety and depression have been reported by the majority of his studied orphans as compared to non-orphans.

According to total self-esteem among the studied orphan children, the findings of the present study showed that, more than half of the studied children had low level of selfesteem. While, less than one quarter of them had moderate level of self-esteem and the minority of them had high level of selfesteem. These results could be justified by various factors such as separation from their families, feeling alone inside orphanage, inability to express their negative emotions openly, mistrust with the place, absence of psychological support. All of these factors lead to anxiety, depression and social isolation and hence low self-esteem.

These results were supported with the study of Devidas \& Mendonca (2017) who showed that more than half of the studied sample had low self-esteem. In the same field, these results were in agreement with the study of Femila et al., (2018) who revealed that the mean score of total self-esteem was low among two thirds of studied sample.

According to the correlation between total child anxiety and depression scale and total self-esteem scale among the studied children, this current study found that, there is a highly statistically significant negative correlation between total child anxiety and depression scale and total self-esteem scale among the studied children. This means when the level of anxiety and depression increase the level of self-esteem decrease. These results were supported with the study achieved by Asif (2017) who mentioned that there was negative correlation between total child anxiety and depression scale and total selfesteem scale among the orphaned children.

\section{Conclusion}

There is highly statistical negative correlation between self-esteem and both of depression and anxiety among the studied children

\section{Recommendations}

> Psychosocial counseling program can be designed and administered to orphan children to improve their behavioral and psychological problems.

- Liaison psychiatric nurses should be available in orphanages to assess the psychological status of orphans and help them effectively.

$>$ Replication of the study using larger sample in different correlational setting to generalized the results.

\section{References}

Abdel Hakeem, N., Abu Bakr, O. \& Hassan, M. (2018). Behavioral and Emotional Problems among Institutionalized Orphans Children, EGYPTION JOURNAL OF HEALTH CARE, Volume 9, Issue 3, September 2018, Page 246-258

Asif, A. (2017). Self-esteem and depression among orphan and non-orphan children. Med Crave Group LLC. 9(3), 246-251.

Chorpita, B. F., Yim, L., Moffitt, C., Umemoto, L. A., \& Francis, S. E. (2000). Assessment of symptoms of DSM-IV anxiety and depression in children: A revised child 


\section{Asmaa Mohamed, Sorayia Ramadan, Mawaheb Mahmoud, Hend Ahmed}

anxiety and depression scale. Behaviour research and therapy, 38(8), 835-855.

Devidas, N., \& Mendonca, T. (2017). A study to evaluate the effectiveness of art therapy on self esteem among the orphans in selected orphanages at Mangalore. Asian Journal of Nursing Education and Research, 7(3), 376-378.

Dhaka, P., \& Mukwiilongo, A. (2020). Emotional maturity assessment of children living in residential homes in Namibia. Emotional and Behavioural Difficulties, 25(1), 3-14.

Elattar, N., Alabd, A., \& Mohammed, R. (2019). Impact of Orphan Children's Emotional and Behavioral Problems and Length of Institutionalization on Their Life Satisfaction. EAS J Nurs Midwifery 1(3), 7682 .

El-Slamoni, M., \& Hussien, R. (2019). Depressive symptoms and aggressive behavior among orphanage female children. Egyptian Nursing Journal, 16(1), 45.

Femila, P., Kiruba, A., \& Appavu, S. (2018). A Study to Assess the Effect of Movement Therapy on Self-Esteem Among Orphaned Children in Selected Orphanage at Kanyakumari District. International Journal of Neurological Nursing, 4(2), 36-42

Hakeem, N., Bakr, O., \& Hassan, M. (2018). Behavioral and Emotional Problems among Institutionalized Orphans Children. Egyptian Journal of Health Care, 9(3), 246251.

Helles, A. (2021). Designing Stimulating Environment to Alleviate Orphan Children Psychological Problems. European Journal of Environment and Public Health, 5(2).
Johnson, A., (2020). Examining associations between racism, internalized shame, and selfesteem among African Americans. Cogent Psychology. ; 7(1):757 -857.

Kaur, R., Vinnakota, A., Panigrahi, S., \& Manasa, V. (2018). A descriptive study on behavioral and emotional problems in orphans and other vulnerable children staying in institutional homes. Indian journal of psychological medicine, 40 (2), 161-168.

Kovalenko, A. (2019). Interpersonal relationships of older preschool-age children who are under institutional care. SOCIAL WELFARE:

INTERDISCIPLINARY APPROACH, 1(9), 47-56.

Rosenberg, M. (1965). Society and the adolescent self-image. Princeton, NJ: Princeton University Press. Online pdf here :( https://www.Docdroid.net/Vt9 $\mathrm{xpBg} /$ societyand-the-adolescent-self-image-morrisrosenberg-1965.Pdf) Accessed on Feb 2020.

Saboula, N., Hussien, A., \& El-Refaee, E. (2017). Occurrence and consequences of violence among orphaned institutionalized children in Menoufia Governorate. IOSR J Nurs Health Sci, 4, 26-38.

Shafiq, F., Haider, S. I., \& Ijaz, S. (2020). Anxiety, Depression, Stress, and DecisionMaking Among Orphans and Non-Orphans in Pakistan. Psychology research and behavior management, 13, 313.

Shiferaw, G., Bacha, L., \& Tsegaye, D. (2018). Prevalence of depression and its associated factors among orphan children in orphanages in Ilu Abba Bor Zone, South West Ethiopia. Psychiatry journal, 2018. 


\section{المشاكل النفسية بين الأطفال الأيتام}

أسماء محمد السعبد عبد الله ـ ثريا رمضان عبد الفتاح- مو اهب محمود زكي ـ هند أحمد مصطفى حسنين

يعتبر فقدان أحد الوالدين أو كليهما مأساة مزدوجة للاطفال. حيث لا يترتب عليها فقط الفقد والحزن المرتبطة بفقدان الو الدين ، بل أيضا الضغوط الاضافية الناشئة بعد وفاتهما. لذلك هدفت الدراسة إلى تقييم تأثير المشاكل النفسية لدى الاطفال الايتام. أجريت الدراسة في مؤسسة الرعاية الاجتماعية للايتام الذكور ومؤسسة الرعاية الجتماعية للايتام الاناث في مدينة بنها بمحافظة القليوبية على • ^ طفلا يتيما ، حيث كثفت النتائج عن وجود علاقة ارتباط سلبية ذات دلالة إحصائية عالية بين مقياس القلق والكتئاب وبين مقياس روزنبرج للثقه بالنفس لاى هؤلاء الاطفال الايتام الخاضعين للار اسة.كما اوصت الدراسة بضرورة تصميم برنامج الإرشاد النفسي و الاجتماعي و إدارته للأطفال الأيتام لتحسين مشاكلهم السلوكية والنفسية. 